UDK: 821.163.41'255.4-31=111; 811.163.41'255.4=111

\title{
PERSPEKTIVA NARATORA I PROBLEM ETNIČKE ODREĐENOSTI U PREVODIMA ANDRIĆEVIH ROMANA NA DRINI ĆUPRIJA I TRAVNIČKA HRONIKA NA ENGLESKI
}

\author{
ALEKSANDRA MILČIĆ RADOVANOVIĆ ${ }^{1}$ \\ International Baccalaureate Organization, \\ Crnjanski High School, \\ International Baccalaureate Diploma Programme, \\ Beograd, Srbija
}

U svojim istorijskim romanima Na Drini ćuprija i Travnička hronika Ivo Andrić prikazuje značajne događaje na prostorima koje naseljava nacionalno i verski raznoliko stanovništvo. Trudeći se da kroz usputne odrednice i upravni govor u što većoj meri odredi etničku pripadnost svojih likova, Andrićev narator često sa tog aspekta određuje svoju pripadnost. Ovakva nacionalna i verska obeležja mogu praviti probleme prevodiocima ovih dela na engleski jezik. U ovom radu polemiše se o postupcima u kojima prevodioci moraju da tragaju za semantičkim ekvivalentima u nekim drugim jezičkim elementima izvan onih koji postoje u originalnom delu. S obzirom na to da je bilo nemoguće sa visokim stepenom sigurnosti utvrditi da li su prevodioci ostvarili potpuni semantički i stilistički transfer, autoru je ostala jedino mogućnost da iznese određene primedbe koristeći slučajeve u kojima se može tačno locirati i objasniti greška u transferu na osnovu opozicije tačno/netačno.

Ključne reči: Andrić, komparativna stilistika, prevođenje.

Dobar prevod bi trebalo da omogući delu da ima istu svrhu koju je imalo i u jeziku izvorniku, ne menjajući njegov sadržaj ili osnovnu formu. Pri tome ne treba zaboraviti na potrebe čitalaca za prirodnim tokom pripovedanja koji je u duhu jezika primalaca, ali i na neizbežnu težnju da se čitaocima prevoda opisani događaji pokažu približno u skladu sa njihovom kulturom kako bi sam tekst bio razumljiv i prijemčiv za čitanje. Dobar prevodilac treba da obrati pažnju kako na očigledne, tako i na skrivene probleme u tekstu prilikom prevođenja. Samo na taj način će izbeći da napravi neoprostive greške kao što su netačan prevod ili besmislene konstrukcije.

1 Kontakt podaci (Email): buskica9@gmail.com 
Andrićeva identifikacija sa likovima koje srećemo u njegovim romanima Na Drini ćuprija i Travnička hronika i podražavanje njihovog načina izražavanja posmatrane sa aspekta jezičke logike predstavljaju jedan od mogućih ključeva za otvaranje dubinskih i skrivenih značenja njegovog dela. Povremeno poistovećivanje autora sa naratorom, ali i sa pojedinim likovima dela pri obraćanju čitaocima, značajno je ne samo pri analizi piščevog stvaralačkog procesa, već i u definisanju odnosa njegovog dela prema stvarnosti „kao dijalektičko-dinamičkoj uključenosti čovjeka u svekolika zbivanja oko sebe" (Tutnjević 1980: 392).

Govoreći o čestoj upotrebi prvog lica u romanesknom pripovedanju Ive Andrića, Ronela Aleksander povezuje ovu osobinu Andrićevog stila sa njegovim stalnim isticanjem bitnosti priče i pričanja, jer su „priče koje ljudi pričajui prepričavaju stvarnije od istina kojima se priča bavi" (Alexander 1995: 202). Na ovaj način se jednom, na prvi pogled, isključivo formalnom elementu pridaje veliki značaj za razumevanje nekih od bitnih aspekata Andrićevih dela. Naime, pripovedačeva upotreba zamenice prvog lica množine "mi" u ova dva romana može se razumeti na nekoliko načina, pa se samim tim čitaocu ostavlja mogućnost izbora prilikom identifikacije. Tako, na primer, može se pretpostaviti, s obzirom na lokaciju događaja u romanu Na Drini ćuprija, da se prvo lice množine odnosi na stanovnike Višegrada, ali i da može biti izraz kolektivnog identiteta stanovnika Bosne, a šire gledano, i svih onih prostora na kojima dolazi do dodira Istoka i Zapada. Ronela Aleksander to objašnjava na sledeći način: „Andrić svom čitaocu nudi slobodan izbor u odnosu prema oblicima prvog lica množine, utoliko što se oni mogu tumačiti kao da uključuju ili isključuju čitaoca, ili se pak čitalac može prema njima odnositi dvojako, prema vlastitom kreativnom nahođenju." (Alexander 1995: 220) Kako su se prevodioci snašli sa ovim problemom pokazaćemo u daljoj analizi.

Prevodeći roman Na Drini ćuprija Lovet Edvards nije previše vodio računa 0 doslednosti pri određivanju lica, tako da je od ukupno 53 primera adekvatno preveo tek 25 , dok je u ostalim prvo lice zamenio uglavnom trećim licem množine. Ovim postupkom je, suprotno Andrićevom nastojanju da se približi čitalačkoj publici, izolovao čitaoca od teksta u odnosu na naratora i ograničio mu mogućnost identifikacije. Naime, Andrić ovaj postupak ne koristi isključivo kao stilski efekat, već i da bi naznačio osećanje etničke ili nacionalne pripadnosti. Samim tim, koristeći se ovom pripovedačkom perspektivom, Andrić uspeva da direktno, ali efektno naglasi tenzije izmeću pripadnika različitih vera koji žive na ovim prostorima. Zato vrlo često ova zamenica pokazuje da se određeni problemi posmatraju iz hrišćanske ili muslimanske, a ponekad samo iz pravoslavne (odnosno, srpske) perspektive.

Tako u primeru gde, govoreći o poturicama, narator u prvom licu kaže: „Mnogi naš poturica koji, promenivši verom, nije našao ono što je očekivao, nego je i dalje sedao za tanku večeru i išao prodrtih laktova..." (Andrić 1985: 33) Ovde se jasno vidi da je ubacivanjem prvog lica množine narator imao nameru da se definiše kao pripadnik hrišćanskog stanovništva, želeći da se ogradi od muslimanskog življa i koristeći izraz pežorativnog prizvuka „poturica”. Izostavljanjem oblika prvog lica, kao i upotrebom sintagme "converted Turks" (,preobraćeni Turci') koja nije stilski markirana, gubi se perspektiva pripovedanja, kao što nestaje isticanje nacionalne pripadnosti onoga koji pripoveda: 
Many of the converted Turks who, in changing faith, had not found what they had hoped for, but had continued to sit down to a merge supper and go about with patched elbows... (Andrić 2000: 35)

Još restriktivniju upotrebu zamenice prvog lica množine srećemo u situaciji kad narator želi da stvari sagleda iz ugla višegradskih Srba. Kao primere navešćemo tri događaja: priča o legendi koja se odnosi na grob starog srpskog junaka Radisava, Prvi srpski ustanak i Prvi svetski rat. U sva ova tri slučaja upotreba zamenice "mi“ postaje restriktivna. Navešćemo ove primere redom kako smo ih i pomenuli:

Naše žene veruju da ima po jedna noć u godini kad se može videti kako na tu [Radisavljevu] humku pada jaka bela svetlost pravo sa neba. (Andrić 1985: 11)

The Serbian women believe that there is one night of the year when a strong light can be seen falling on that tumulus direct from heaven. (Andrić 2000: 18)

Za vreme Karađorđeve bune srećemo sledeću sliku:

Naše žene su se krstile u tami i plakale od nerazumljivog ganuća, a u suzama su im se lomile ove ustaničke vatre kao oni avetinjski plamenovi koji su nekad padali na Radisavljev grob... (Andrić 1985: 90)

The Serbian women crossed themselves in the darkness and wept from inexplicable emotion, but in their tears they saw reflected those fires on insurrection even as those ghostly flames which had once fallen upon Radisav's grave... (Andrić 2000: 83)

Kao što smo već rekli, ovaj primer srećemo i kada se govori o početku Prvog svetskog rata, za vreme šuckorskog terora nas Srbima:

U Ristića kući, koja je odmah iznad parohove, veća i lepša od nje, a sklonjena i zaštićena od topovske vatre sa obe strane strmim šljivicima, sklonilo se najviše našeg sveta iz čaršije. (Andrić 1985: 351)

The merchants from the market- place had for the most part taken refuge in the Ristic house. It was immediately above the priest's house, but larger and fine, sheltered from artillery fire by the steep slopes of the plum orchards. (Andrić 2000: 295)

Iz navedenih primera vidimo da L. Edvards ovakvim prevodnim postupkom ne ostavlja čitaocu mogućnost identifikacije sa naratorom. U prva dva navedena slučaja on izostavlja prvo lice, ali tačno tumači etničku pripadnost naratora, pa fraze „naše žene" prevodi kao "Srpkinje” (,Serbian women'). U trećem primeru nacionalna naznaka i perspektiva naratora se u potpunosti gube, pa je sintagma "naš svet" prevedena kao „the merchants from the market- place“" (,trgovci sa pijace') čime se nikako ne označava etnička određenost trgovaca iz čaršije. 
Interesantno je primetiti da ovakvih grešaka gotovo da nema u prevodu dela Travnička hronika. To se može obrazložiti željom pisca da u ovom romanu pokaže život u Travniku iz perspektive austrijskog i francuskog konzula, tako da nema značajnije upotrebe prvog lica množine u pripovedanju naratora, a kada ga i ima prevedeno je istim oblikom i odnosi se uglavnom na jednistvo pripovedača i čitalaca, bez preciziranja nacionalnosti, godina ili prostora sa koga potiče. To se može videti iz navedenih primera:

Dužnost ćehaje, vezirova zamenika, vršio je Sulejman-paša Skopljak, koji je i kod ranijeg vezira, kao što smo videli, zauzimao isti položaj. (Andrić 1976:213)

The Deputy was Suleiman Pasha Skopljak, who had held the same post under the former Vizier, as we have seen. (Andrić 1996: 168)

Ta vremena posle Bečkog mira (1810. i 1811. godina), koja smo nazvali mirnim godinama, bila su u stvari za Davila vremena velikog rada. (Andrić 1976:397)

The years after the Peace of Vienna (1810 and 1811), which we have referred to as a peaceful spell, were in fact a time of great activity for Daville. (Andrić 1996: 316)

Tako izgleda, tipično uzevši, postanak, razvoj i svršetak uzbune po našim varošima. (Andrić 1976:183)

This is the typical pattern of the beginning, progress and the end of riots in our towns. (Andrić 1996: 143)

Samo na dva mesta nalazimo na izuzetak od ovoga pravila. Upoznajući sa čitaoce sa Davilovim tumačem Davnom prevodilac sintagmu "naš svet" zamenjuje oblikom „Christian" (,hrišćani'), pri čemu nedvosmisleno određuje perspektivu svog pripovedanja.

Kao veza između Konaka i novog konzula služio je vezirov lekar i tumač César d'Avenat, koga su i Osmanlije i naš svet zvali Davna. (Andrić 1976: 27)

The Vizier's doctor and interpreter Cesar d' Avenat acted as a link between the Residence and the new Consul. To all the locals, Muslim and Christian alike, he was known as „Davna” (Andrić 1996: 15).

Na drugom mestu govoreći o prilagođavanju gospođe Davil oštroj travničkoj zimi, narator kaže:

Umotana u šal od sivog kašmira, žustra i žilava, obilazi povazdan ogromnu tursku kućerinu, naređuje šta treba da se radi, teško se sporazumeva sa poslugom, zbog neznanja jezika i neveštine našeg sveta u poslovima... (Andrić 1976: 146) 
Wrapped in a grey cashmere shawl, brisk and indomitable, she spent the whole day going round the huge Turkish house, deciding what needed to be done and giving instructions. She found it difficult to communicate with the servants because of her ignorance of the language and the slovenly ways of the local people. (Andrić 1996: 112)

Prevodilacovusloženu rečenicu,tipičnuzaAndrićevstil, razlaže na dvejednostavnije i konstrukciju "neveštine našeg sveta" prevodi sa "slovenly ways of the local people" („neurednost lokalnog stanovništva“). Može se reći da je ovakav prevod poprilično neprecizan, ako znamo da se narator deklariše s aspekta pripadnika hrišanskog naroda, a da je Travnik u to vreme naseljen kako hrišćanskim, tako i muslimanskim življem. Izraz "local people" (,lokalno stanovništvo') iskorišćen u prevodu odnosi se na sve stanovnike grada Travnika i okoline, nezavisno od njihove verske i nacionalne pripadnosti, čime se gubi perspektiva pripovedanja.

Preciznost prevoda i odsustvo grešaka koje smo naveli u prevodu dela Na Drini ćuprija može se takođe objasniti i saradnjom Silije Hoksvort sa Bogdanom Rakićem o čemu govori i ona sama. U predgovoru izdanja iz 1992. Silija kaže da je Andrića zaista teško prevoditi, ali da je mnoge nedoumice rešila zahvaljujući sugestijama Bogdana Rakića koji ima odličan osećaj kako za engleski jezik, tako i za svoj maternji, srpskohrvatski (Andrić 1996: 9).

Koliko god sve ove pojedinosti izgledale zanemarljive, svaka od njih ima svoje mesto i stilističku funkciju u građenju poetskih slika u romanu, s obzirom na to da nedvosmisleno ukazuju na podeljenost lokalnog stanovništva koja je uzrok svega opisanog u ovim romanima. Takođe, nacionalna i verska šarolikost čine deo stvarne istorijske pozadine koja simbolički povezuje realne događaje i one opisane u delima, a sa blagim osvrtom na pojavu ljudske solidarnosti i zanemarivanja tih razlika pred većim životnim problemima.

Međutim, kod Loveta Edvardsa srećemo vrlo često mešanje pojmova, kao i njihovu zamenu, što negativno utiče na sadržajnu percepciju dela, pogotovo kad se radi o pojmovima koji imaju nacionalnu konotaciju. Tako on u velikom broju slučajeva bosanske muslimane naziva Turcima čime se čitaoci na engleskom i američkom području dovode u zabludu jer im se nameće pogrešan civilizacijski kontekst, a samim tim se uskraćuje tačna i neizostavna informacija o multietničkom stanovništvu na području Bosne. Čak i Andrić na početku Rečnika turcizama, provincijalizama i nekih manje poznatih stranih izraza navodi objašnjenje da „nazivi Turci i turski upotrebljeni su često u toku pričanja i za bosanski muslimanski svet, naravno ne u rasnom i etničkom smislu, nego kao pogrešni, ali tada uobičajeni nazivi" (Andrić 1976: 535). Pored toga, Edvards reč „Vlah" na nekoliko mesta ostavlja u ovom obliku (,Vlach') simbolizujući tako pripadnost različitoj etničkoj grupi, ali pri tome primarno značenje ove reči „otpadnik“ gotovo zanemaruje, prevodeći je na taj način na samo jednom mestu.

Tu se razgovor izmetnu u prostu svađu u kojoj je Osman efendija nazvao Alihodžu vlahom i murtatinom, jednim od onih izdajnika čije glave, kao i vlaške, treba da okapaju na ovoj kapiji... (Andrić 1985: 130) 
The conversation then degenerated into an open quarrel in which 0sman Effendi referred to Alihodja as a renegade, one of those traitors whose heads, like the Serbs', should be exposed on the kapia... (Andrić 2000: 116)

Vidimo da je ovde konstrukcija "vlahom i murtatinom" prevedena samo sa "renegade" (,otpadnik'), pričemuje „vlah" napisano malim slovom što pokazuje da se ne sugeriše etnička pripadnost, već se upotrebljena reč odnosi na pogrdan izraz uobičajen za to vreme. Ne možemo da ne primetimo da je pridev "vlaški" preveden sa "srpski" čime ova reč u navedenom kontekstu dobija pravi smisao. Različitim prevođenjem ove reči gubi se onaj element etničke tenzije koji Andrić pokušava da dočara koristeći turske izraze za pripadnike pojedinih naroda. Vrlo mudro, da bi izbegla ovakve greške Silija Hoksvort reč „vlah" prevodi najčešće sa "Christian” (,hrišćanin') izostavljajući tako pežorativnost izraza, ali i smanjujući mogućnost nerazumevanja naratorovog etničkog određenja.

Mnoštvo ovakvih etničkih pojedinosti ostalo je nejasno ili pogrešno u prevodu Loveta Edvardsa. Tako, na primer, govoreći o običajima višegradskih stanovnika Andrić u jednom delu kaže: „0 slavama i božićima ili u ramazanskim noćima, sedi, otežali i brižni domaćini živnuli bi i postali razgovorni čim bi došao govor na najveći i najteži događaj njihovog života, na ,povodanj"'. (Andrić 1985: 80)

U Edvardsovom prevodu početna fraza preinačena je tako da se potpuno gubi smisao koji ukazuje na konfesionalnu podeljenost kasabe. Zamenom fraze „o slavama i božićima ili u ramazanskim noćima" konstrukcijom "on feast days and festivals" (,u dane kad su praznici i proslave'), koja se odnosi uopšte na svečanosti nevezane za crkvene praznike, gubi se pojam o suprotstavljenosti hrišćanskog i muslimanskog načina života. Evo kako to izgleda u delu: "On feast days and festivals and during the nights of Ramazan the grey-haire toilworn and anxious fathers of families would grow lively and talkative when the conversation turned to the greatest and hardest event of their lives, to the great flood." (Andrić 2000: 75)

Sličnu sliku srećemo u sceni kad se Efendi Karamanlija obraća višegradskim Turcima sa željom da ih ubedi da se pridruže pobuni protiv austrijske vojske. U prevodu je prikazano kako se Karamanlija u govoru obraća "narodu Višegrada” (,the people of Višegrad'), što je pored netačnog prevoda i, grubo rečeno, istorijska prevara jer se stvara pogrešna slika o odnosu dva različita entiteta u Bosni prema austrijskoj okupaciji. Naime, iako postoje podaci da su Srbi povremeno pružali otpor, to nikako nije bio slučaj sa Srbima koji su živeli na području Višegrada. Sve ovo vidi se iz sledećih primera:

Ne mogući se duže zadržavati, muftija im pripreti narodnim sudom i božjim gnevom i ostavi svog pomoćnika Osman-efendiju Karamanliju da dalje ubeđuje višegradske Turke o potrebi njihovog učešća u opštem ustanku. (Andrić 1985: 127)

Unable to control himself any longer he threatened them with the justice of the people and the anger of the God and then left his assistant Osman Effendi Karamanli to go on convincing the people of Višegrad of the need for their participation in a general insurrection. (Andrić 2000: 114) 
Zdenko Lešić govoreći o jeziku umetničkog dela u knjizi Jezik i književno djelo navodi jedan odlomak iz Travničke hronike, gde kaže da Andrićeve rečenice sadrže brojne istoriografske, biografske i druge vrednosti, ali da "njihova funkcija nije u tome da prenesu stvarnu informaciju o jednoj istorijskoj činjenici, već da kreiraju jedan svijet, koji, ako i nije sasvim imaginaran, ipak je svijet imaginacije." (Lešić 1982: 41) On dalje iznosi kako svi elementi teksta učestvuju u strukturi značenja i doprinose poetskoj funkciji romana. Razvijajući ovo razmišljanje u svom radu Stilistika fonijskih struktura u Andrićevoj „Travničkoj hronici" Radoje Simić (Simić 2000: 32) smatra da je ovakav zaključak opravdan, jer raspored jedinica u leksičkoj distribuciji i njihovo učešće u izgradnji iskaznih formi u Andrićevim romanima predstavljaju značajne elemente u metodi stilske transfiguracije. U brojnim greškama pri prevođenju pojedinosti ove vrste i ostalih etničkih detalja gubi se lokalna i istorijska boja Andrićevog romana, koja je jedno od najznačajnih obeležja njegovog stila. Iz svega rečenog, nameće nam se zaključak da se Ivo Andrić, kao stvaralac univerzalnih sposobnosti, nije oslanjao isključivo na intuiciju i utisak koji postiže upotrebom ekspresivnih leksičkih sredstava. On je ugradio veliki broj podataka o određenim nacionalnim, verskim i kulturnim pitanjima koje je pažljivo prikupljao i analizirao, pokušavajući da unese i istorijske činjenice u delo, ali i celokupno kulturno nasleđe naroda i prostora koji prikazuje. Možemo zato slobodno reći da se Andrić u ovim romanima potrudio da jezički imenuje ambijent Bosne i da je zbog toga, pri prevođenju njegovih istorijskih romana, potrebno voditi računa o perspektivi naratora i etničkoj pripadnosti likova i govornika u delu.

\section{LITERATURA}

Alexander, R. 1995. Narrative Voice and Listener's Choice in the Prose of Ivo Andrić. GAIA Research Series. New York: UC Berkeley.

Andrić, I. 1976. Travnička hronika. Sarajevo: Svjetlost.

Andrić, I. 1985. Na Drini ćuprija. Beograd: BIGZ.

Andrić, I. 1996. Bosnian chronicle or The days of the consuls, prev. S. Hoksvort. London: The Harvill Press.

Andrić, I. 2000. The Bridge on the Drina, prev. L. Edvards. Beograd: Dereta.

Lešić, Z. 1982. Jezik i književno djelo. Sarajevo: Svjetlost.

Simić, R. 2000. Stilistika fonijskih struktura u Andrićevoj „Travničkoj hronici”. Književnost i jezik XLVII/3-4.

\section{SUMMARY}

\section{NARRATOR'S PERSPECTIVE AND THE PROBLEM OF ETHNICAL DETERMINATION IN ENGLISH TRANSLATION OF IVO ANDRIĆ'S NOVELS NA DRINI ĆUPRIJA AND TRAVNIČKA HRONIKA}

In historical novels The Bridge on the Drina and Bosnian Chronicle Ivo Andrić describes notable events in the region populated by ethnically and religiously diverse population. Using incidental remarks and direct and indirect speech which largely 
determine the ethnicity of its characters, Andrićs narrator often uses this aspect to determine his own nationality. Ethnic and religious characteristics like these can cause many problems to translators of these novels into English. In this paper author examines various ways in which interpreters have to look for semantic equivalents in other elements of the language than those that exist in the original work. Since it was impossible with a high degree of certainty to determine whether the translators made a complete semantic and stylistic transfer, author of this paper can only express some observations using the cases in which one can accurately locate and explain possible errors in the transfer of the opposition true/ false.

KEYWORDS: Andrić, comparative stylistics, translation.

(Original naučni rad primljen 26.01.2011;

ispravljen 12.7.2011;

prihvaćen 01.12.2011) 